\title{
Dampak Shock Kebijakan Moneter Terhadap Ketimpangan Pendapatan di Indonesia
}

\author{
Meylinda Sulfiana Putri ${ }^{1^{*}}$, Wasiaturrahma ${ }^{2}$ \\ 1,2 Departemen Ilmu Ekonomi, Fakultas Ekonomi dan Bisnis Universitas Airlangga
}

\section{Informasi Artikel \\ Sejarah artikel: \\ Diterima April 2019 \\ Disetujui Oktober 2019 \\ Dipublikasikan Oktober 2019}

\section{Keywords:}

Income Inequality,

Monetary Policy,

Monetary Policy Shock

Income Composition Channel

\begin{abstract}
A B S T R A C T
Households have different sources of income, and the heterogeneity of income will make the interest rates from monetary policy have a different impact because the effect of redistribution so that it will eventually cause the differences in income distribution. The channel of monetary policy redistribution shows how the transmission mechanism of monetary policy affect income distribution and eventually have an impact on income inequality. This study aims to find out and analyze the impact of monetary policy on income inequality in Indonesia in 1995Q1 - 2017Q4 and examine one of the channels of the transmission mechanism that is income composition channel. The analytical method used is Vector Error Correction Model, this is based on the existence of a cointegration relationship in the analysis model used. The results of the study show that contractionary monetary policy by raising interest rates can increase income inequality and on the contrary expansive monetary policy can reduce income inequality. Expansive monetary policy can encourage economic activity, reduce unemployment and increase income especially for low-income households, so that this condition can produce a better income distribution.
\end{abstract}




\section{PENDAHULUAN}

Ketimpangan pendapatan telah menjadi salah satu masalah ekonomi global yang sampai saat ini masih menjadi isu hampir di seluruh negara di dunia khususnya negara-negara berkembang termasuk Indonesia. Berdasarkan data Indeks Gini (net income inequality) yang dihimpun oleh Standarized World Income Inequality Database, semenjak krisis ekonomi tahun 1997-1998 nilai Indeks Gini Indonesia cenderung mengalami peningkatan. Selama kurun waktu 19 tahun terakhir nilai Indeks Gini meningkat dari angka 34,7 di tahun 1999 menjadi 39,3 di tahun 2017. World Bank (2016) menyebutkan bahwa tingkat ketimpangan di Indonesia relatif tinggi dan naik lebih pesat dibandingkan banyak negara di Asia Timur lainnya. Badan Perencanaan Pembangunan Nasional (2012) dan World Bank (2016) menyebutkan secara umum terdapat empat faktor utama yang mendorong ketimpangan yaitu ketimpangan peluang hidup yang layak yang diakibatkan sejak awal kehidupan yang kurang baik sehingga mempengaruhi kualitas sumber daya manusia, pekerjaan yang tidak merata, kekayaan yang terkonsentrasi pada sekelompok orang serta ketahanan ekonomi yang rendah.

Selain itu, United Nations Development Programme (2013) juga menyebutkan bahwa terdapat faktor endogen dan eksogen penyebab ketimpangan pendapatan. Faktor eksogen tersebut diantaranya adanya globalisasi termasuk globalisasi perdagangan dan globalisasi keuangan (Ghossoub \& Reed, 2017; United Nations Development Programme, 2013) serta kemajuan teknologi (Acemoglu, 2002). Faktor endogen tersebut adalah berupa kebijakan makro ekonomi seperti kebijakan fiskal dan moneter. Analisis kebijakan fiskal cenderung diyakini mampu menurunkan ketimpangan melalui pengaturan permintaan dan pengeluaran yang dilakukan oleh pemerintah yang pada akhirnya akan berpengaruh pada distribusi pendapatan.
Disisi lain dampak distribusi dari kebijakan moneter cenderung diabaikan dan dianggap tidak memiliki keterkaitan dengan ketimpangan pendapatan. Bernanke (2015) menjelaskan bahwa kebijakan moneter adalah alat tumpul yang tentu saja mampu mempengaruhi distribusi pendapatan dan dalam jangka panjang kebijakan moneter memiliki dampak nyata pada distribusi pendapatan dan kekayaan. Isu ketimpangan pendapatan kini tengah menjadi persoalan di sejumlah bank sentral terkait dengan kebijakan moneter yang ditempuh bank sentral dan dampak redistribusi yang ditimbulkan (Areosa \& Areosa, 2016).

Beberapa penelitian empiris membuktikan bahwa kebijakan moneter dapat mempengaruhi ketimpangan pendapatan melalui efek redistribusi yang ditimbulkan dan kebijakan moneter dapat mempengaruhi distribusi pendapatan melalui mekanisme transmisi yang berbeda. Beberapa penelitian empiris tersebut menjelaskan bahwa setidaknya terdapat lima saluran redistribusi kebijakan moneter yang menjelaskan bagaimana kebijakan moneter dapat mempengaruhi ketimpangan pendapatan (Areosa \& Areosa, 2016; Casiraghi et al., 2018; Coibion et al., 2017; Furceri et al., 2017; Davtyan, 2017; Koedijk et al., 2018; Mumtaz \& Theophilopoulou, 2017; Nakajima, 2015).

Pertama, saluran komposisi pendapatan (income composition channel) yang menjelaskan bahwa sumber pendapatan rumah tangga berbeda satu dengan yang lainnya. Rumah tangga sebagian besar pendapatannya bergantung pada upah dari hasil bekerja, sementara rumah tangga lainnya mampu mendapatkan pendapatan lebih dari kepemilikan aset finansial. Kebijakan moneter ekspansif akan lebih menguntungkan rumah tangga yang memiliki aset finansial (sejauh mereka lebih kaya) yang pada akhirnya akan meningkatkan ketimpangan pendapatan. 
Kedua, saluran heterogenitas penghasilan tenaga kerja (earnings heterogeneity channel) menjelaskan bahwa penghasilan tenaga kerja adalah sumber utama pendapatan bagi sebagian besar rumah tangga dan penghasilan ini dapat merespon secara berbeda untuk rumah tangga yang berpenghasilan tinggi maupun rendah terhadap guncangan kebijakan moneter. Saluran ini menggambarkan bahwa pengahasilan tenaga kerja dibagian distribusi bawah cenderung dipengaruhi oleh fluktuasi bisnis dan pada saat yang sama mereka biasanya menerima pendapatan tambahan dari transfer pemerintah dan transfer cenderung tersebut counter cyclical. Kebijakan moneter ekspansif cenderung akan menurukan ketimpangan pendapatan (Coibion et al., 2017; Davtyan, 2017).

Ketiga, saluran portofolio (portfolio channel) yang menjelaskan redistribusi pendapatan berdasarkan struktur aset yang dimiliki. Rumah tangga berpenghasilan rendah umumnya cenderung memegang uang tunai sedangkan rumah tangga berpenghasilan tinggi cenderung memiliki berbagai portofolio atau aset finansial. Kebijakan moneter ekspansif akan meningkatkan laju inflasi sehingga merugikan rumah tangga berpenghasilan rendah dan menguntungkan rumah tangga yang memiliki aset finansial karena mereka akanmenyesuaikan portofoliomereka, yang pada akhirnya kondisi ini akan menyebabkan ketimpangan pendapatan meningkat.

Keempat, saluran segmentasi keuangan (financial segmentation channel) yang menjelaskan realokasi pendapatan terhadap agen-agen yang terlibat dalam pasar keuangan yang dapat mengambil keuntungan dari guncangan kebijakan moneter ekspansif. Umumnya agen yang terlibat dipasar keuangan adalah rumah tangga yang berpendapatan tinggi sehingga ketika mereka sering melakukan transaksi dipasar keuangan, maka guncangan kebijakan moneter ekspansif akan cenderung mendistribusikan kekayaan terhadap agen yang paling terhubung dengan pasar keuangan dan kondisi ini cenderung akan meningkatkan ketimpangan pendapatan ketika rumah tangga berpendapatan rendah tidak terlibat di pasar keuangan. Kelima, saluran redistribusi tabungan (saving redistribution channel) menjelaskan bahwa peningkatan inflasi atau penurunan suku bunga akan menguntungkan peminjam namun tidak menguntungkan bagi penabung. Channel ini mengasumsikan bahwa penabung umumnya lebih kaya daripada peminjam maka guncangan kebijakan moneter eskpansif akan mengurangi ketimpangan melalui saluran ini.

Beberapa penelitian empiris menjelaskan bahwa kebijakan moneter kontraktif akan meningkatkan ketimpangan pendapatan (Areosa \& Areosa, 2016; Coibion et al., 2017; Furceri et al., 2017; Guerello, 2018; Mumtaz\& Theophilopoulou, 2017; Casiraghi et al., 2018). Disisi lain hasil penelitian empiris lainnya menjelaskan bahwa kebijakan moneter kontraktif mampu menurunkan ketimpangan pendapatan (Davtyan, 2017; Villareal, 2014). Perbedaan hasil penelitian empiris sebelumnya di berbagai negara menjadi hal yang penting untuk dilakukan penelitian yang sama di Indonesia dan menganalisis bagaimana dampak kebijakan moneter baik itu ekspansif maupun kontraktif terhadap ketimpangan pendapatan di Indonesia.

Berbeda dengan penelitian sebelumnya, hal yang menarik dalam penelitian ini adalah mencoba untuk menguraikan bagaimana mekanisme kebijakan moneter bisa berdampak terhadap ketimpangan pendapatan di Indonesia. Adanya keterbatasan data mikro pada total pendapatan rumah tangga, maka saluran yang paling memungkinkan untuk diteliti adalah hanya income composition channel sama halnya dengan penelitian Coibion et al. (2017). Bernanke (2015) mengamati bahwa cara 
yang lebih baik untuk melihat efek distribusi kebijakan moneter adalah dengan membandingkan perubahan dalam pendapatan yang mengalir dari investasi modal dengan pendapatan dari tenaga kerja dan salah satu saluran yang menunjukkan kondisi tersebut adalah melalui income composition channel. Melalui channel tersebut akan dilihat apakah income composition channel bekerja atau tidak sebagai salah satu saluran redistribusi kebijakan moneter di Indonesia.

Berhubungan dengan kebijakan moneter, dinamika kebijakan suku bunga bank sentral sangat krusial pengaruhnya bagi kondisi perekonomian termasuk pada pelaku ekonomi itu sendiri dan salah satunya berpengaruh pada pendapatan mereka. Oleh karena itu, mengingat sangat pentingnya persoalan ketimpangan pendapatan serta peran kebijakan moneter yang sangat strategis, maka penelitian ini menjadi penting untuk dilakukan terlebih isu penelitian secara empiris mengenai dampak kebijakan moneter terhadap ketimpangan pendapatan di Indonesia masih sangat jarang dilakukan. Penelitian ini diharapkan dapat memberikan referensi bagi Bank Indonesia dalam meninjau kembali rancangan kebijakan moneter yang optimal dan menentukan jenis kebijakan yang tepat yang tepat karena adanya efek redistribusi dari kebijakan moneter.

\section{METODE PENELITIAN}

Pengukuran Ketimpangan Pendapatan

Pengukuran tingkat ketimpangan pendapatan menggunakan data Indeks Gini yang diperoleh dari Standardized World Income Inequality (SWIID v7.1). Data SWIID merupakan rangkuman data dari beberpa sumber seperti United Nations University's World Income Inequality Database, OECD Income Distribution Database, World Bank, Eurostat, Luxembourg Income Study dan kantor statistik nasional di 192 negara yang kemudian di standarisasi.
Variabel Indeks Gini yang digunakan dalam peneltiian ini menggunakan pengukuran ketimpangan berdasarkan net income inequality (post-tax, post-transfer) yang nilainya berada dalam rentang 0-100 berdasarkan Standardized World Income Inequality. Penggunaan net income inequality didasarkan karena net income inequality mampu mengendalikan efek distribusi kebijakan fiskal yaitu pajak dan transfer. Data Indeks Gini hanya tersedia pada frekuensi tahunan sehingga untuk mendapatkan data dalam frekuensi kuartalan dilakukan metode interpolasi dari tahunan menjadi kuartalan seperti halnya penelitian Davtyan (2017) dan hal tersebut dapat dibenarkan karena rangkaiannya memiliki variasi yang rendah. Metode interpolasi yang digunakan adalah menggunakan interpolasi "quadratic-matchaverage" pada frequency version.

Pengukuran Shock Kebijakan Moneter Pengukuran shock kebijakan moneter mengacu pada model persamaan penelitian Furceri et al. (2017) yang menggunakan exogenous monetary policy shock yaitu unexpected interest rate yang dilakukan melalui dua tahap pengukuran.

Pertama adalah menghitung Forecast Error (FE) suku bunga dengan persamaan berikut:

$$
F E_{t}^{r}=S T_{t}^{r}-C T_{t}^{r}
$$

Dimana $F E_{i, t}^{r}$ adalah forecast error suku bunga jangka pendek. $S T_{i, t}^{r}$ adalah suku bunga aktual jangka pendek yang dalam penelitian ini menggunakan $\mathrm{Bl}$ Rate. $C T_{i, t}^{r}$ adalah short term interest rate forecast yang dilakukan oleh lembaga atau analisis setiap tahunnya.

Kedua adalah melakukan regresi dari hasil perhitungan forecast error suku bunga $F E_{i, t}^{r}$ pada persamaan 1 diatas dengan forecast error inflasi $\left(F E_{t}^{\text {inf }}\right)$ dan forecast error GDP growth $\left(F E_{t}^{g}\right.$ ) dengan persamaan berikut:

$$
F E_{t}^{r}=\alpha_{t}+\beta F E_{t}^{\text {inf }}+\gamma F E_{t}^{g}+\epsilon_{t}
$$


Dimana $\left(F E_{t}^{\text {inf }}\right)$ adalah forecast error inflasi yang diperoleh dari nilai inflasi aktual dikurangi nilai inflation forecast yang dilakukan oleh lembaga atau analisis setiap tahunnya. ( $F E_{t}^{g}$ ) adalah forecast error GDP growth yang diperoleh dari nilai GDP growth aktual dikurangi nilai GDP growth forecast yang dilakukan oleh lembaga atau analisis setiap tahunnya. Ketersediaan data forecasting untuk Indonesia baik suku bunga, inflasi maupun GDP growth relatif tidak pada sampel yang panjang sehingga dalam penelitian untuk memperoleh data forecasting maka digunakan teknik ekonometrika yaitu Hodrick-Prescott (HP) Filter. Nilai residual dari hasil regresi tersebut digunakan sebagai shock kebijakan moneter. Penggunaan exogenous monetary policy shock dapat mengatasi dua masalah yang sebaliknya dapat mengaburkan estimasi efek kausal guncangan kebijakan moneter pada ketimpangan (Furceri et al., 2018).

Pertama dengan menggunakan forecast error akan menghilangkan masalah "policy foresight". Pelaku ekonomi dapat menerima informasi tentang perubahan dalam kebijakan moneter sebelumnya dan dapat mengubah perilaku konsumsi dan investasi mereka dengan baik sebelum perubahan dalam kebijakan terjadi sehingga perubahan dalam kebijakan tersebut tidak akan memberikan pengaruh. Sebuah teknik ekonometrika hanya mampu menggunakan informasi yang terkandung dalam perubahan tingkat kebijakan yang sebenarnya dan hal itu bergantung pada kumpulan informasi yang lebih kecil daripada yang digunakan oleh pelaku ekonomi yang mengarah ke perkiraan yang tidak konsisten dari dampak guncangan kebijakan moneter. Forecast error dalam metodologi ini secara efektif menyeleraskan kumpulan informasi pelaku ekonomi dan ekonometrika (Furceri et al., 2018). Kedua dengan menggunakan perubahan yang tidak terduga pada pertumbuhan ekonomi dan inflasi melalui forecast error jangka pendek mampu mengurangi kemungkinan potensi adanya respon endogen dari kebijakan moneter terhadap perubahan pertumbuhan ekonomi atau inflasi.

Adapun variabel yang digunakan untuk membuktikan income composition channel yaitu upah tenaga kerja sebagai representasi dari pendapatan upah serta income deposit dan stock market capitalization sebagai representasi dari pendapatan aset finansial. Variabel upah tenaga kerja yang digunakan adalah ratarata upah bulanan tenaga kerja yang diperoleh dari Survei Angkatan Kerja Nasional Badan Pusat Statistik Indonesia yang selanjutnya diinterpolasi menjadi bentuk kuartal. Variabel income deposit adalah pendapatan deposito yang diperoleh dari data jumlah deposito perorangan (data bersumber dari Bank Indonesia) dikalikan dengan suku bunga deposito (data bersumber dari International Monetary Fund). Variabel stock market capitalization adalah nilai kapitalisasi pasar saham yang diperoleh dari Bank Indonesia. Semua variabel akan diubah ke dalam bentuk logaritma natural kecuali variabel shock kebijakan moneter dan indeks gini.

\section{Teknik Analisis Data}

Teknik analisis data yang digunakan untuk mengetahui dampak kebijakan moneter terhadap ketimpangan pendapatan adalah menggunakan Vector Error Corection Model (VECM). Model VECM digunakan di dalam model VAR non struktural ketika data time series tidak stasioner pada tingkat level, namun terkointegrasi. Model VECM mampu meretriksi hubungan perilaku jangka panjang antar variabel yang ada agar konvergen ke dalam hubungan kointegrasi tetapi tetap membiarkan adanya perubahan-perubahan dinamis di dalam jangka pendek (Lütkepohl \& Kratzig, 2004). Tahapan dalam estimasi persamaan menggunakan model VECM adalah uji stasioneritas, penentuan panjang lag optimum, uji kau- 
salitas Granger, uji kointegrasi Johansen dan estimasi model VECM (impulse response function dan variance decomposition).

Adapun teknik analisis yang digunakan untuk membuktikan bekerjanya mekanisme income compostion channel adalah melalui uji kausalitas granger. Pertama akan diuji bagaimana pengaruh shock unexpected interest rate terhadap pendapatan yang berasal dari upah dan pendapatan yang berasal dari kepemilikan aset finansial yang direpresentasikan oleh variabel income deposit dan stock market capitalization. Kedua akan diuji bagaimana pengaruh upah, income deposit, stock market capitalization terhadap Indeks Gini. Apabila nilai probabilitas dari hasil uji kausalitas granger dibawah $1 \%, 5 \%$ atau $10 \%$ maka dapat disimpulkan bahwa income composition channel bekerja sebagai salah satu saluran redistribusi kebijakan moneter dan begitu pula sebaliknya.

Adapun model analisis dalam penelitian ini adalah sebagai berikut:

$$
\begin{array}{r}
\Delta \text { Gini }_{t}=\alpha_{7}+\sum_{i=1}^{n} \alpha_{8} \Delta G i n i_{t-i}+\sum_{i=1}^{n} \alpha_{9} \Delta M P_{t-i}+\sum_{i=1}^{n} \alpha_{10} \Delta \text { Wage }_{t-i}+ \\
\sum_{i=1}^{n} \alpha_{11} \Delta I D_{t-i}+\sum_{i=1}^{n} \alpha_{12} \Delta S C_{t-i}+\sum_{i=1}^{n} \alpha_{13} \Delta D_{t-i}+\lambda_{14} \varepsilon_{1 t-1}+\mu_{1 t} \\
\Delta M P_{t}=\beta_{7}+\sum_{i=1}^{n} \beta_{8} \Delta M P_{t-i}+\sum_{i=1}^{n} \beta_{9} \Delta G i n i_{t-i}+\sum_{i=1}^{n} \beta_{10} \Delta W a g e_{t-i}+ \\
\sum_{i=1}^{n} \beta_{11} \Delta I D_{t-i}+\sum_{i=1}^{n} \beta_{12} \Delta S C_{t-i}+\sum_{i=1}^{n} \beta_{13} \Delta D_{t-i}+\lambda_{14} \varepsilon_{2 t-1}+\mu_{2 t} \\
\Delta W a g e_{t}=\gamma_{7}+\sum_{i=1}^{n} \gamma_{8} \Delta W a g e_{t-i}+\sum_{i=1}^{n} \gamma_{9} \Delta G i n i_{t-i}+\sum_{i=1}^{n} \gamma_{10} \Delta M P_{t-i}+ \\
\sum_{i=1}^{n} \gamma_{11} \Delta I D_{t-i}+\sum_{i=1}^{n} \gamma_{12} \Delta S C_{t-i}+\sum_{i=1}^{n} \gamma_{13} \Delta D_{t-i}+\lambda_{14} \varepsilon_{3 t-1}+\mu_{3 t} \\
\Delta I D_{t}=\theta_{7}+\sum_{i=1}^{n} \theta_{8} \Delta I D_{t-i}+\sum_{i=1}^{n} \theta_{9} \Delta G i n i_{t-i}+\sum_{i=1}^{n} \theta_{10} \Delta M P_{t-i}+ \\
\sum_{i=1}^{n} \theta_{11} \Delta W a g e_{t-i}+\sum_{i=1}^{n} \theta_{12} \Delta S C_{t-i}+\sum_{i=1}^{n} \theta_{13} \Delta D_{t-i}+\lambda_{14} \varepsilon_{4 t-1}+\mu_{4 t}
\end{array}
$$

$$
\begin{array}{r}
\Delta S C_{t}=\omega_{7}+\sum_{i=1}^{n} \omega_{8} \Delta S C_{t-i}+\sum_{i=1}^{n} \omega_{9} \Delta \operatorname{Gini}_{t-i}+\sum_{i=1}^{n} \omega_{10} \Delta M P_{t-i}+ \\
\sum_{i=1}^{n} \omega_{11} \Delta \text { Wage }_{t-i}+\sum_{i=1}^{n} \omega_{12} \Delta I D_{t-i}+\sum_{i=1}^{n} \omega_{13} \Delta D_{t-i}+\lambda_{14} \varepsilon_{5 t-1}+\mu_{5 t}
\end{array}
$$

Dimana Gini adalah Indeks Gini, $M P$ adalah shock kebijakan moneter (unexpected interest rate), Wage adalah log upah, ID adalah log income deposit, SC adalah log stock market capitalization, $\varepsilon_{t}$ adalah error term. $D$ adalah variabel dummy krisis ekonomi 1998 yang digunakan untuk mengetahui ada tidaknya structural break dalam penelitian sehingga model penelitian dapat mengakomodasi perubahan dalam ekonomi akibat krisis ekonomi. Adapun dummy 0 untuk sebelum krisis ekonomi 1998 dan 1 untuk setelah krisis ekonomi 1998. Selanjutnya $\mu_{t}$ adalah error term, $\lambda$ adalah koefisien kecepatan penyesuaian dan $\varepsilon_{t-1}$ adalah error correction term.

\section{HASIL DAN PEMBAHASAN \\ Uji Stasioneritas}

Pengujian stasioneritas dilakukan dengan membandingkan ADF statistik dengan critical value, jika ADF lebih besar dari critical value maka data tersebut stasioner dan sebaliknya. Selain itu juga bisa dilakukan dengan melihat nilai probabilitasnya, apabila probabilitas dibawah 1\%, 5\% dan $10 \%$ maka data tersebut stasioner dan sebaliknya. Dari hasil uji stasioneritas data diperoleh hasil hanya variabel indeks gini, shock kebijakan moneter dan log income deposit yang stasioner pada tingkat level sedangkan variabel log stock market capitalization tidak stasioner pada tingkat level. Selanjutnya variabel yang tidak stasioner tersebut dilanjutkan pada uji stasioneritas dengan equation test first difference. Hasilnya variabel log stock market capitalization stasioner pada tingkat first difference, sedangkan variabel log wage stasioner pada tingkat second difference. 
Tabel 1.

Hasil Uji Stasioneritas pada Equation Test Level

\begin{tabular}{|c|c|c|c|c|c|c|}
\hline \multirow[b]{2}{*}{ Variabel } & \multirow{2}{*}{$\begin{array}{c}\text { ADF } \\
\text { Statistik }\end{array}$} & \multicolumn{3}{|c|}{ Critical Value } & \multirow{2}{*}{ Prob. } & \multirow{2}{*}{ Ket. } \\
\hline & & $1 \%$ & $5 \%$ & $10 \%$ & & \\
\hline Indeks Gini & $-3,709$ & $-4,068$ & $-3,462$ & $-3,157$ & 0,027 & \multirow{5}{*}{$\begin{array}{l}\text { Stasioner } \\
\text { Stasioner } \\
\text { Stasioner } \\
\text { Tidak } \\
\text { Stasioner } \\
\text { Tidak } \\
\text { Stasioner }\end{array}$} \\
\hline Shock kebijakan moneter & $-8,454$ & $-2,591$ & $-1,944$ & $-1,614$ & 0,000 & \\
\hline Log income deposit & $-3,784$ & $-4,063$ & $-3,460$ & $-3,156$ & 0,022 & \\
\hline $\begin{array}{l}\text { Log stock market } \\
\text { capitalization }\end{array}$ & $-2,602$ & $-4,063$ & $-3,460$ & $-3,156$ & 0,280 & \\
\hline Log wage & $-2,381$ & $-4,073$ & $-3,465$ & $-3,159$ & 0,386 & \\
\hline
\end{tabular}

Sumber: Eviews 8 (diolah)

Tabel 2.

Hasil Uji Stasioneritas pada Equation Test First Difference

\begin{tabular}{lcccccc}
\hline \multirow{2}{*}{ Variabel } & ADF & \multicolumn{3}{c}{ Critical Value } & \multirow{2}{*}{ Prob. } & \multirow{2}{*}{ Ket. } \\
\cline { 3 - 5 } & Statistik & $1 \%$ & $5 \%$ & $10 \%$ & & \\
\hline Log stock market & $-7,504$ & $-4,063$ & $-3,460$ & $-3,156$ & 0,000 & Stasioner \\
$\begin{array}{l}\text { capitalization } \\
\text { Log wage }\end{array}$ & $-2,377$ & $-4,074$ & $-3,465$ & $-3,159$ & 0,388 & $\begin{array}{l}\text { Tidak } \\
\text { Stasioner }\end{array}$ \\
\hline
\end{tabular}

Sumber: Eviews 8 (diolah)

Tabel 3.

Hasil Uji Stasioneritas pada Equation Test Second Difference

\begin{tabular}{lcccccc}
\hline \multirow{2}{*}{ Variabel } & ADF & \multicolumn{3}{c}{ Critical Value } & \multirow{2}{*}{ Prob. } & Ket. \\
\cline { 3 - 6 } & Statistik & $1 \%$ & $5 \%$ & $10 \%$ & & \\
& $-5,896$ & $-4,073$ & $-3,465$ & $-3,159$ & 0,000 & Stasioner \\
\hline Log wage & & & & & &
\end{tabular}

Sumber: Eviews 8 (diolah)

\section{Penentuan lag optimum}

Dari hasil pengujian lag lenght criteria, beberapa ktiteria informasi seperti Likehood Ratio, Final Prediction Error dan Aike Information Criterion menujukkan bahwa lag 8 adalah lag yang optimum dan paling banyak direkomendasikan, sehingga dalam penelitian ini akan digunakan lag 8 untuk estimasi selanjutnya.

\section{Uji Kausalitas Granger}

Uji kausalitas Granger digunakan untuk menentukan apakah shock kebijakan moneter secara statistik berpengaruh terhadap Indeks Gini, selain itu untuk melihat apakah income composition channel bekerja sebagai salah satu saluran redistribusi kebijakan moneter. Suatu variabel memiliki hubungan kausalitas apabila memiliki nilai probabilitas lebih kecil dari $5 \%$.

Tabel 4.

Hasil Uji Lag Optimum

\begin{tabular}{ccccccc}
\hline Lag & LogL & LR & FPE & AIC & SC & HQ \\
\hline 0 & -241.1588 & NA & 0.000279 & 6.003874 & 6.150625 & 6.062792 \\
1 & 185.0929 & 790.1251 & $1.57 \mathrm{e}-08$ & -3.782753 & -2.902246 & -3.429243 \\
2 & 290.9040 & 183.2339 & $2.20 \mathrm{e}-09$ & -5.753756 & $-4.139493^{*}$ & -5.105654 \\
3 & 326.8401 & 57.84837 & $1.71 \mathrm{e}-09$ & -6.020490 & -3.672471 & -5.077797 \\
4 & 368.0533 & 61.31719 & $1.19 \mathrm{e}-09$ & -6.415934 & -3.334159 & $-5.178649^{*}$ \\
5 & 387.7495 & 26.90217 & $1.43 \mathrm{e}-09$ & -6.286574 & -2.471043 & -4.754697 \\
6 & 429.6412 & 52.10920 & $1.03 \mathrm{e}-09$ & -6.698567 & -2.149280 & -4.872098 \\
7 & 459.8283 & 33.86846 & $1.03 \mathrm{e}-09$ & -6.825082 & -1.542039 & -4.704021 \\
8 & 502.0320 & $42.20366^{*}$ & $8.04 \mathrm{e}-10^{*}$ & $-7.244683^{*}$ & -1.227885 & -4.829031 \\
\hline
\end{tabular}

Sumber: Eviews 8 (diolah) 
Tabel 5.

Hasil Uji Kausalitas Granger

\begin{tabular}{lll}
\hline Hipotesis & F- Stat. & Prob. \\
\hline SHOCK $\rightarrow$ GINI & 2.11810 & 0.0462 \\
GINI $\rightarrow$ SHOCK & 3.34849 & 0.0028 \\
SHOCK $\rightarrow$ DDLWAGE & 1.35204 & 0.2345 \\
DDLWAGE $\rightarrow$ SHOCK & 0.71077 & 0.6810 \\
SHOCK $\rightarrow$ LID & 4.14413 & 0.0005 \\
LID $\rightarrow$ SHOCK & 6.62012 & $2 . E-06$ \\
SHOCK $\rightarrow$ DLSC & 4.45805 & 0.0002 \\
DLSC $\rightarrow$ SHOCK & 0.35046 & 0.9423 \\
DDLWAGE $\rightarrow$ GINI & 0.42026 & 0.9048 \\
GINI $\rightarrow$ DDLWAGE & 0.16135 & 0.9951 \\
LID $\rightarrow$ GINI & 1.58814 & 0.1453 \\
GINI $\rightarrow$ LID & 2.33233 & 0.0285 \\
DLSC $\rightarrow$ GINI & 1.04852 & 0.4097 \\
GINI $\rightarrow$ DLSC & 1.86776 & 0.0801 \\
LID $\rightarrow$ DDLWAGE & 0.68746 & 0.7010 \\
DDLWAGE $\rightarrow$ LID & 0.61736 & 0.7601 \\
DLSC $\rightarrow$ DDLWAGE & 0.43531 & 0.8956 \\
DDLWAGE $\rightarrow$ DLSC & 0.76888 & 0.6312 \\
DLSC $\rightarrow$ LID & 1.24344 & 0.2885 \\
LID $\rightarrow$ DLSC & 1.92086 & 0.0714 \\
\hline
\end{tabular}

Sumber: Eviews 8 (diolah)

Berdasarkan uji kausalitas Granger diperoleh hasil bahwa variabel shock unexpected interest rate secara statistik signifikan mempengaruhi Indeks Gini dengan nilai probabilitas 0,0462 . Dengan demikian dapat disimpulkan bahwa kebijakan moneter memiliki pengaruh terhadap ketimpangan pendapatan. Selain itu shock kebijakan moneter secara statistik juga signifikan mempengaruhi income deposit dengan probabilitas 0,0005 dan stock market capitalization dengan probabilitas 0,0002 .

\section{Uji Kointegrasi Johansen}

Dari hasil uji stasioneritas diperoleh hasil bahwa tidak semua variabel stasioner pada tingkat level, oleh karena itu perlu

Tabel 6.

Hasil Uji Kointegrasi Johansen

\begin{tabular}{|c|c|c|c|c|c|}
\hline \multicolumn{6}{|c|}{ Trace Statistic Test } \\
\hline $\begin{array}{l}\text { Hypothesized No. } \\
\text { of CE(s) }\end{array}$ & Lag & Eigenvalue & $\begin{array}{c}\text { Trace } \\
\text { Statistic }\end{array}$ & $\begin{array}{c}5 \% \text { Critical } \\
\text { Value }\end{array}$ & Prob. \\
\hline None $^{*}$ & 8 & 0.511105 & 99.92539 & 60.06141 & 0.0000 \\
\hline At most $1^{*}$ & 8 & 0.210440 & 41.96117 & 40.17493 & 0.0327 \\
\hline At most 2 & 8 & 0.140799 & 22.82249 & 24.27596 & 0.0754 \\
\hline At most 3 & 8 & 0.110276 & 10.53056 & 12.32090 & 0.0980 \\
\hline At most 4 & 8 & 0.013076 & 1.066178 & 4.129906 & 0.3508 \\
\hline \multicolumn{6}{|c|}{ Maximum Eigenvalue Test } \\
\hline $\begin{array}{l}\text { Hypothesized No. } \\
\text { of CE(s) }\end{array}$ & Lag & Eigenvalue & $\begin{array}{c}\text { Trace } \\
\text { Statistic }\end{array}$ & $\begin{array}{c}5 \% \text { Critical } \\
\text { Value }\end{array}$ & Prob. \\
\hline None $^{*}$ & 8 & 0.511105 & 57.96422 & 30.43961 & 0.0000 \\
\hline At most 1 & 8 & 0.210440 & 19.13868 & 24.15921 & 0.2071 \\
\hline At most 2 & 8 & 0.140799 & 12.29192 & 17.79730 & 0.2770 \\
\hline At most 3 & 8 & 0.110276 & 9.464386 & 11.22480 & 0.1004 \\
\hline At most 4 & 8 & 0.013076 & 1.066178 & 4.129906 & 0.3508 \\
\hline
\end{tabular}

Sumber: Eviews 8 (diolah) 
dilakukan uji kointegrasi dengan menggunakan metodologi kointegrasi Johansen.

Pengujian menggunakan nilai trace test menunjukkan bahwa terdapat 2 rank yang memiliki kointegrasi, sedangkan menggunakan maximum eigenvalue test menunjukkan bahwa terdapat 1 rank yang memiliki kointegrasi. Jika dibandingkan dengan maximum eigenvalue test, pengujian menggunakan trace test terkadang memiliki ukuran yang lebih terdistorsi dalam sampel kecil jika diimplementasikan sebagai tes kointegrasi (Lutkepohl dan Kratzig, 2004). Oleh karena itu dalam penelitian ini akan digunakan rank 1 dalam estimasi VECM selanjutnya mengacu pada hasil maximum eigenvalue test. Hal tersebut sejalan dengan penelitian Davtyan (2017) yang juga menggunakan maximum eigenvalue test sebagai tes kointegrasi. Berdasarkan hasil uji kointegrasi, telah dibuktikan bahwa terdapat kointegrasi sehingga model Vector Error Corection Model lebih tepat digunakan untuk mengestimasi persamaan dalam penelitian ini.

Estimasi Vector Error Corection Model Estimasi Vector Error Corection Model dalam penelitian ini secara khusus digunakan untuk mengetahui dampak dari guncangan kebijakan moneter terhadap ketimpangan pendapatan. Adapun hasl dari estimasi Vector Error Corection Model pada variabel indeks gini sebagai variabel dependen dan shock kebijakan moneter (unexpected interest rate) sebagai variabel independen adalah sebagai berikut:

Gujarati (2008) menjelaskan bahwa untuk mengestimasi model VAR ataupun VECM dapat menggunakan seperti halnya regresi OLS dan interpretasi dari hasil estimasi tersebut dengan melihat variabel yang signifikan saja. Enders (2015) menyebutkan model VAR akan menjadi overparameterized karena banyak dari estimasi koefisien yang tidak signifikan, sehingga untuk interpretasi cukup dilakukan pada koefisien variabel yang signifikan karena tujuannya adalah untuk menemukan hubungan yang penting diantara variabel. Dari hasil estimasi tersebut hanya variabel shock pada lag 1, lag 2 dan lag 3 yang signifikan dengan nilai t statistik lebih besar dari t tabel. Lag 1 dan lag 3 signifikan pada tingkat signifikansi 5 persen dengan nilai t tabel 1,99, sedangkan lag 2 signifikan pada tingkat signifikansi 10 persen dengan nilai $t$ tabel 1,66. Untuk mengetahui dampak dari kebijakan moneter terhadap ketimpangan pendapatan adalah dengan menjumlahkan koefisien dari variabel shock yang signifikan yaitu $\mathrm{D}(\mathrm{SHOCK}(-1)) \mathrm{D}(\mathrm{SHOCK}(-2))$ dan $\mathrm{D}(\mathrm{SHOCK}(-3))$. Apabila hasil penjumlahan

Tabel 7.

Hasil Estimasi Vector Error Corection Model

\begin{tabular}{ccc}
\hline Variabel & \multicolumn{2}{c}{$\mathrm{D}(\mathrm{GINI})$} \\
\cline { 2 - 3 } & Koefisien & $\mathrm{t}$ - statistik \\
\hline CointEq1 & $-0,000550$ & $-1,60770$ \\
D(SHOCK $(-1))$ & 0,003020 & 2,68231 \\
D(SHOCK(-2)) & 0,002033 & 1,73547 \\
D(SHOCK(-3)) & 0,002812 & 2,13726 \\
D(SHOCK(-4)) & 0,002066 & 1,39550 \\
D(SHOCK(-5)) & 0,001481 & 1,02996 \\
D(SHOCK(-6)) & 0,001239 & 0,86565 \\
D(SHOCK(-7)) & 0,000297 & 0,25276 \\
D(SHOCK(-8)) & 0,000424 & 0,46762 \\
\hline
\end{tabular}

Sumber: Eviews 8 (diolah) 
bernilai positif menunjukkan adanya peningkatan ketimpangan pendapatan akibat kebijakan moneter kontraktif dan sebaliknya hasil penjumlahan bernilai negatif menunjukkan adanya penurunan ketimpangan pendapatan akibat kebijakan moneter kontraktif. Dari hasil estimasi jumlah dari ketiga koefisien tersebut bernilai positif dengan nilai sebesar 0,007865 . Oleh karena itu hasil tersebut menunjukkan kenaikan suku bunga akibat kebijakan moneter kontraktif dapat meningkatkan ketimpangan pendapatan.

Analisis Impulse Response Function (IRF)

Analisis impulse response function (IRF) digunakan untuk mengetahui respon dari suatu variabel terhadap adanya guncangan variabel lain. Secara khusus analisis impulse response function akan digunakan untuk mengetahui bagaimana respon dari indeks gini terhadap shock kebijakan moneter dalam suatu rentang periode tertentu. Guerello (2018) serta Saiki \& Frost (2014) menjelaskan analisis Impulse Response Function (IRF) akan lebih berguna untuk mengevaluasi dampak kebijakan moneter terhadap dispersi pendapatan dengan menganalisis IRF kumulatif, karena mampu mengumpulkan keseluruhan dampak pada setiap titik waktu. Beberapa penelitian sebelumnya juga menggunakan analisis Impulse Response Function (IRF) untuk mengetahui respon dari guncangan (shock) kebijakan moneter terhadap indeks gini dan mengukur seberapa besar dampaknya (Davtyan, 2017; Furceri et al, 2017; Guerello, 2018; Mumtaz\& Theophilopoulou, 2017; Coibion et al, 2017; Casiraghi et al, 2018; Villareal, 2014; Saiki \& Frost, 2014). Hasil analisis Impulse Response Function indeks gini terhadap shock kebijakan moneter menunjukkan pada periode pertama indeks gini tidak merespon shock kebijakan moneter yang artinya pada periode pertama shock kebijakan moneter (unexpected interest rate) tidak memiliki dampak terhadap indeks gini. Pada periode kedua dan seterusnya indeks gini merespon positif akibat adanya shock kebijakan moneter dan nilainya terus mengalami peningkatan.
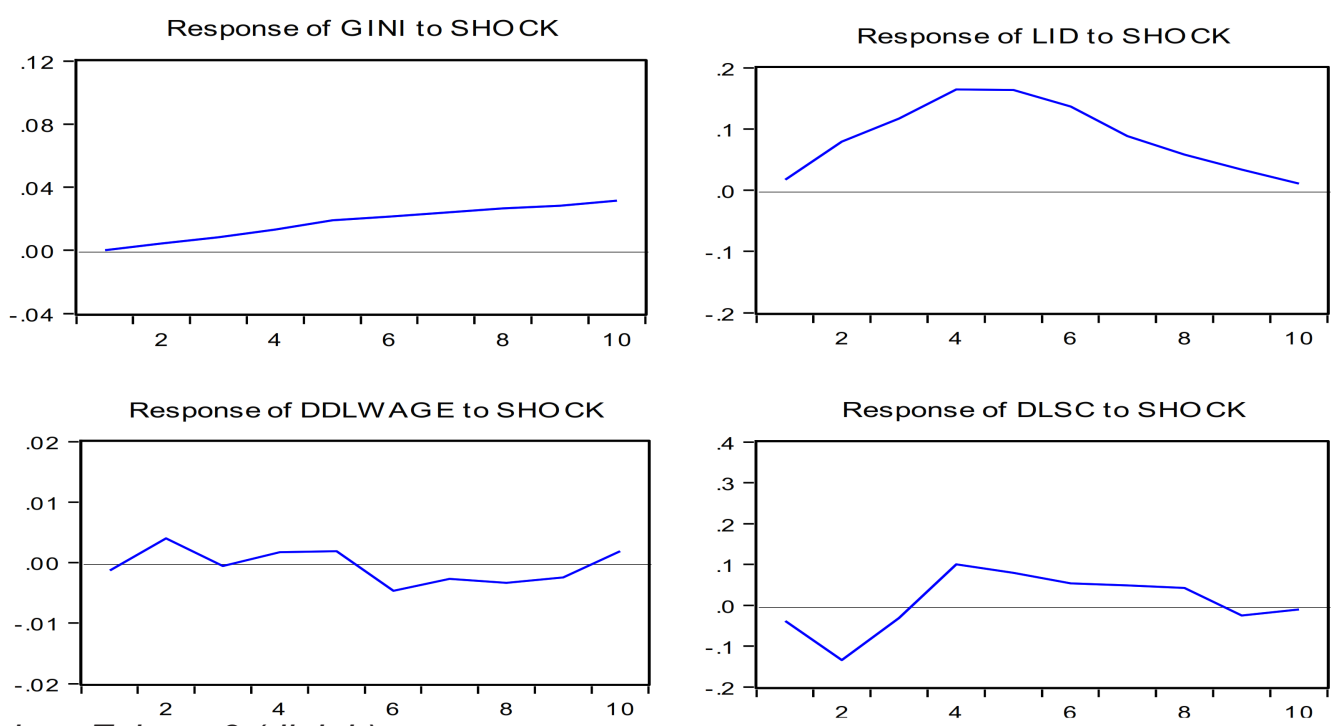

Sumber: Eviews 8 (diolah)

Gambar 1. Hasil analisis IRF terhadap shock kebijakan moneter 
Pada pendapatan aset finansial, hasil analisis Impulse Response Function menunjukkan pada periode pertama income deposit merespon secara positif akibat adanya shock kebijakan moneter dan nilainya terus meningkat hingga periode kelima, pada periode keenam dan seterusnya nilainya mengalami penurunan namun masih dalam trend positif. Hasil analisis Impulse Response Function stock market capitalization terhadap shock kebijakan moneter menunjukkan pada periode pertama stock market capitalization merespon secara negatif akibat adanya shock kebijakan moneter hingga periode ketiga. Pada periode keempat responnya mulai bergerak naik hingga periode kedelapan kemudian kembali direspon secara negatif pada periode kesembilan dan kesepuluh.

\section{Analisis Variance Decomposition}

Analisis variance decomposition bertujuan untuk mengukur besarnya kontribusi atau komposisi pengaruh masing-masing variabel. Secara khusus, dalam analisis variance decomposition ini dapat menjelaskan bagaimana kontribusi pengaruh shock kebijakan moneter terhadap variabel indeks gini. Berdasarkan analisis variance decomposition menunjukkan pada periode pertama shock kebijakan moneter tidak mempengaruhi indeks gini. Shock kebijakan moneter mulai mempengaruhi indeks gini pada periode kedua sebesar 2,91 persen. Nilai komposisi shock kebijakan moneter terus meningkat hingga periode kedelapan dengan nilai 7,76 persen dan diperiode selanjutnya nilai komposisi shock kebijakan moneter mengalami penurunan hingga diperiode kesepuluh mencapai 7,18 persen.

Berdasarkan hasil uji kausalitas granger pada tabel 5 menunjukkan bahwa shock kebijakan moneter (unexpected interest rate) memiliki pengaruh terhadap indeks gini. Berdasarkan cointegrating equation pada hasil estimasi Vector Error Corection Model menunjukkan bahwa kenaikan suku bunga akibat kebijakan moneter kontraktif dapat meningkatkan ketimpangan pendapatan. Hasil penelitian ini sejalan dengan beberapa penelitian sebelumnya seperti Furceri et al. (2017), Coibion et al. (2017), Mumtaz\&Theophilopoulou(2017), Guerello (2017) dan Casiraghi et al. (2018) yang juga menunjukkan bahwa guncangan kebijakan moneter kontraktif dapat meningkatkan ketimpangan pendapatan dan sebaliknya kebijakan moneter ekspansif dapat menurunkan ketimpangan pendapatan.

Romer\&Romer(1999)menjelaskan bahwa pada jangka pendek kebijakan moneter ekspansif dikaitkan dengan kondisi yang lebih baik untuk orang miskin karena adanya penurunan ketimpangan

Tabel 8.

Hasil Analisis Variance Decomposition Indeks Gini

\begin{tabular}{ccccccc}
\hline Periode & S.E & Gini & Shock & Log Upah & Log ID & Log SC \\
\hline 1 & 0.012428 & 100.0000 & 0.000000 & 0.000000 & 0.000000 & 0.000000 \\
2 & 0.026333 & 96.40041 & 2.911146 & 0.440711 & 0.203872 & 0.043858 \\
3 & 0.045776 & 93.70805 & 4.265855 & 1.040506 & 0.688803 & 0.296786 \\
4 & 0.070287 & 91.72015 & 5.365439 & 1.650596 & 0.948579 & 0.315232 \\
5 & 0.094482 & 88.59339 & 7.044940 & 2.918934 & 1.065393 & 0.377339 \\
6 & 0.119833 & 87.05668 & 7.527380 & 4.022813 & 0.938986 & 0.454137 \\
7 & 0.146377 & 85.92754 & 7.742322 & 5.078568 & 0.754322 & 0.497247 \\
8 & 0.174486 & 84.99792 & 7.760387 & 6.073465 & 0.567931 & 0.600295 \\
9 & 0.206089 & 84.90699 & 7.427304 & 6.512233 & 0.417010 & 0.736466 \\
10 & 0.240430 & 84.84110 & 7.180369 & 6.815048 & 0.311984 & 0.851495 \\
\hline
\end{tabular}

Sumber: Eviews 8 (diolah) 
pendapatan. Kebijakan moneter akan mempengaruhi aktivitas perekonomian melalui transmisi kebijakan moneter dengan melibatkan interaksi antara perbankan dengan pelaku ekonomi di sektor riil. Kebijakan moneter dapat mempengaruhi ketimpangan pendapatan melalui aksebilitas keuangan termasuk pada akses perbankan. Seberapa banyak masyarakat mampu mengakses produk dari layanan keuangan, khususnya masyarakat yang berpendapatan rendah. Di tingkat mikro, transaksi keuangan yang bersifat produktif dapat menciptakan kesempatan kerja dan memberikan kesempatan kepada masyarakat untuk meningkatkan pendapatannya (Akyuwen \& Mangowal, 2017).

Produk dan layanan pada jasa keuangan terutama pada perbankan dapat dimanfaatkan oleh masyarakat miskin berpendapatan rendah ataupun kelompok masyarakat miskin yang kurang produktif. Misalnya seperti fasilitas pinjaman dari perbankan yang akan sangat membantu masyarakat khususnya mereka yang berada pada distribusi pendapatan bagian bawah. Berkaitan dengan distribusi pendapatan, pinjaman tersebut dapat dimanfaatkan oleh pelaku usaha untuk membuka usaha atau mengembangkan usahanya sehingga mampu menggerakkan sektor ekonomi dan meningkatkan pendapatan masyarakat.

Mishkin (2016) menyebutkan turunnya suku bunga riil akibat kebijakan moneter ekspansif akan menurunkan biaya riil pinjaman dan hal ini akan menyebabkan kenaikan pada investasi. Pengaruh suku bunga terhadap investasi terjadi karena suku bunga pinjaman merupakan komponen biaya modal (cost of capital), disamping yield obligasi dan dividen saham dalam pembiayaan investasi (Warjiyo \& Juhro, 2016). Pada tingkat suku bunga yang rendah rendah, pelaku usaha di sektor riil akan lebih mudah untuk melakukan ekspansi bisnis karena mampu memperoleh pinjaman modal dengan suku bunga pinjaman yang rendah dari perbankan, sehingga biaya modal yang dikeluarkan juga lebih rendah. Pinjaman tersebut dapat dipergunakan untuk berbagai tujuan misalnya untuk pengadaan mesin baru, pendirian pabrik baru atau cabang usaha di tempat lain dan lain sebagainya. Sisi positifnya kondisi tersebut dapat membuka lapangan kerja baru, tenaga kerja semakin bertambah sehingga jumlah pengangguran juga menurun akibat banyaknya tenaga kerja yang terserap di dalamnya.

Koedijk et al. (2018) menjelaskan peningkatan aktivitas pasar tenaga kerja akibat kebijakan moneter ekspansif akan memberi manfaat besar bagi rumah tangga di bagian bawah distribusi pendapatan karena dapat mengurangi pengangguran sehingga dapat mengurangi ketimpangan pendapatan. Biaya bunga pinjaman yang lebih rendah akan mengurangu biaya modal dan beban usaha, sehingga perusahaan bisa menawarkan gaji yang lebih tinggi pada tenaga kerja. Kondisi demikian akan menguntungkan bagi rumah tangga yang berpendapatan rendah karena adanya peningkatan pendapatan dan dengan demikian akan mampu menghasilkan distribusi pendapatan yang lebih baik.

Disisi lain semakin tinggi suku bunga akibat kebijakan moneter kontraktif menyebabkan biaya modal akan semakin meningkat dan perusahaan akan sulit untuk melakukan eskpansi bisnis. Peluang usaha dan peluang kerja menjadi rendah serta aktivitas perekonomian akan bergerak lambat. Sisi negatifnya peningkatan biaya modal akan memaksa perusahaan untuk menurunkan upah tenaga kerja atau mengurangi jumlah tenaga kerja agar efisiensi perusahaan tetap tercapai. Kondisi ini justru akan menurunkan pendapatan tenaga kerja dan akibatnya distrbusi pendapatan menjadi tidak merata. Berkaitan dengan saluran redistribusi kebijakan moneter, pada saving redistribution chan- 
nel juga menjelaskan bahwa kebijakan moneter kontraktif cenderung akan meningkatkan ketimpangan pendapatan karena kenaikan suku bunga akan merugikan peminjam dan menguntungkan pe-nabung (sejauh penabung umumnya lebih kaya daripada peminjam) dan sebaliknya kebijakan moneter ekspansif mampu mengurangi ketimpangan pendapatan.

Hasil penelitian ini berbeda dengan teori income composition channel yang menjelaskan bahwa kebijakan moneter ekspansif dengan menurunkan suku bunga dapat meningkatkan ketimpangan pendapatan. Hasil penelitian ini menjelaskan bahwa kebijakan moneter ekspansif dapat menurunkan ketimpangan pendapatan di Indonesia. Coibion et al. (2017) menjelaskan kebijakan moneter ekspansif memberikan keuntungan lebih pada kelompok rumah tangga yang memiliki aset finansial dibandingkan kelompok rumah tangga yang hanya memiliki upah, sehingga akan menyebabkan ketimpangan pendapatan yang lebih tinggi melalui channel ini. Coibion et al. (2017) menjelaskan kondisi ini dapat terjadi apabila dengan mempertimbangkan rumah tangga yang memiliki aset finansial umumnya lebih kaya sehingga menimbulkan perbedaan distribusi pendapatan yang lebih tinggi.

Fakta di Indonesia berdasarkan Neraca Rumah Tangga Indonesia tahun 2015-2017 menjelaskan bahwa proporsi sumber pendapatan rumah tangga yang berasal dari pendapatan kepemilikan termasuk didalamnya kepemilikan aset finansial hanya berkisar 3 persen (BPS, 2017). Proporsisumber pendapatan rumah tangga yang berasal dari kepemilikan aset finansial cukup rendah, sehingga adanya penurunan suku bunga akibat kebijakan moneter ekspansif tidak akan terlalu mempengaruhi kondisi distribusi pendapatan. Upah dan gaji merupakan sumber pendapatan rumah tangga yang terbesar, proporsinya mencapai lebih dari 60 persen dari seluruh pendapatan rumah tangga.
Kelompok rumah tangga berpendapatan rendah umumnya mengandalkan upah dari hasil bekerja sebagai sumber utama pendapatan dan kebijakan moneter ekspansif cenderung akan menguntungkan kelompok rumah tangga tersebut melalui peningkatan aktivitas pasar tenaga kerja (Koedjik et al, 2018). Penelitian Kang et al (2013) juga menjelaskan bahwa guncangan kebijakan moneter ekspansif meningkatkan upah dan pendapatan kelompok rumah tangga di bagian bawah distribusi pendapatan sementara rumah tangga di bagian atas distribusi pendapatan kurang terpengaruh karena rumah tangga kaya umumnya memperoleh proporsi pendapatan lebih besar dari investasi. Berkaitan dengan kebijakan moneter ekspansif, menurut Coibion et al. (2017) penurunan suku bunga menguntungkan bagi pemiliki saham dan canderung akan meningkatkan ketimpangan pendapatan, namun disisi lain peningkatan saham tersebut juga dapat dimanfaatkan oleh dunia usaha sebagai sumber pembiayaan investasi. Penurunan suku bunga simpanan akibat kebijakan moneter ekspansif akan menyebabkan rumah tangga yang memiliki aset finansial mengalihkan sebagian simpanannya di bank dalam bentuk saham dan obligasi. Pengaruh intermediasi perbankan terhadap penyediaan pembiayaan kepada dunia usaha melalui pasar modal karena dunia usaha memenuhi kebutuhan pembiayaannya tidak hanya dari kredit perbankan tetapi juga dari emisi saham dan obligasi di pasar modal (Warjiyo \& Juhro, 2016). Misalnya dalam hal suku bunga kredit relatif tinggi atau perbankan membatasi ekspansi kreditnya, maka dunia usaha akan meningkatkan usahanya dengan pembiayaan dari emisi saham atau obligasi yang ditanamkan oleh para investor di pasar modal. Peningkatan pembiayaan dunia usaha akan meningkatkan kemampuan produksi usaha, sektor ekonomi akan berkembang, kesejahteraan masyarakat meningkat dan pada akhirnya 
akan mampu menghasilkan distribusi pendapatan yang lebih baik.

Mekanisme Income Composition Channel

Hasil pengujian income composition channel melalui uji kausalitas granger ditunjukkan pada pada tabel 5. Hasilnya menunjukkan bahwa shock kebijakan moneter hanya mempengaruhi pendapatan finansial yaitu income deposit dan stock market capitalization dengan nilai probabilitas masing-masing 0,0005 dan 0,0002, sedangkan shock tidak mempengaruhi upah karena nilai probabilitas tidak signifikan. Pada tahap selanjutnya, baik pendapatan upah maupun pendapatan aset finansial (income deposit dan stock market capitalization) secara statistik tidak memiliki pengaruh terhadap indeks gini karena nilai probabilitas diatas $5 \%$. Dengan demikian hasil ini menunjukkan bahwa income composition channel tidak bekerja sebagai salah satu saluran redistribusi kebijakan moneter karena tidak ada hubungan antara pendapatan upah dan pendapatan aset finansial terhadap ketimpangan pendapatan.

Kebijakan moneter memang memiliki dampak terhadap ketimpangan pendapatan di Indonesia, namun transmisinya tidak melalui income composition channel. Melihat hasil tersebut, maka ada kemungkinan lima channel lainnya dapat menjadi salah satu saluran redistribusi kebijakan moneter di Indonesia yang memperlihatkan bagaimana mekanisme transmisi kebijakan moneter dapat mempengaruhi ketimpangan pendapatan. Dibutuhkan penelitian lebih lanjut untuk membuktikan channel yang lain.

\section{KESIMPULAN}

Berdasarkan hasil penelitian dapat disimpulkan bahwa kebijakan moneter kontraktif dengan meningkatkan suku bunga dapat meningkatkan ketimpangan pendapatan dan sebaliknya kebijakan moneter ekspansif dengan menurunkan suku bunga dapat menurunkan ketimpangan pendapatan. Berdasarkan pengujian terhadap mekanisme transmisi income composition channel diperoleh hasil bahwa income composition channel tidak bekerja sebagai salah satu saluran redistribusi kebijakan moneter di Indonesia. Ada kemungkinan kebijakan moneter mempengaruhi ketimpangan pendapatan melalui channel lain pada saluran redistribusi kebijakan moneter.

Adanya bukti empiris yang sedang berkembang yang memadukan agen-agen heterogen dan efek redistribusi dari kebijakan moneter maka penelitian ini dapat memberikan pengetahuan baru bagi akademisi maupun praktisi tentang bagaimana kebijakan moneter mampu mempengaruhi ketimpangan pendapatan melalui saluran redistribusi kebijakan moneter. Bukti empiris ini dapat memberikan kontribusi bagi Bank Sentral dalam meninjau kembali rancangan kebijakan moneter yang optimal mengingat adanya efek redistribusi yang ditimbulkan dari kebijakan moneter dan pendapatan rumah tangga yang bersifat heterogen. Hasil ini dapat menjadi bahan pertimbangan bagi Bank Sentral untuk lebih berhati-hati dalam menentukan suku bunga sebagai instrumen kebijakan moneter agar menghasilkan efek redistribusi yang lebih baik dan distribusi pendapatan yang lebih baik pula.

\section{DAFTAR PUSTAKA}

Acemoglu, D. (2002). Technical Change, Inequality, and the Labor Market. Journal of Economic Literature, 40(1), 7-72.

Akyuwen, R., \& Mangowal, C. (2017). Komparasi Peningkatan Inklusi Keuangan dan Indikator Pembangunan di Indonesia. Modus, 30(1), 96-109.

Areosa, W. D., \& Areosa, M. B. M. (2016). The inequality channel of monetary transmission. Journal 
of Macroeconomics, 48, 214-230.

Badan Perencanaan Pembangunan Nasional. (2012). Rasio Gini di Indonesia dalam Lima Tahun Terakhir. https://www.bappenas. go.id/files/3913/5022/6047/rasiogini-di-indonesia-1_201212171431 42_1.pdf. Diakses tanggal 29 Februari 2018.

Badan Pusat Statistik. (2017). Neraca Rumah Tangga Indonesia Tahun 2015-2017.

Bernanke, B. S. (2015). Monetary Policy and Inequality. https://www.brook ings.edu/b/og/ben-bernanke/ 2015/06/01/monetary-policyand-inequality/.

Casiraghi, M., Gaiotti, E., Rodano, L., \& Secchi, A. (2018). A "reverse Robin Hood"? The distributional impli cations of non-standard monetary policy for Italian households. Journal of International Money and Finance, 85, 215-235.

Coibion, O., Gorodnichenko, Y., Kueng, L., \& Silvia, J. (2017). Innocent Bystanders? Monetary policy and inequality. Journal of Monetary Economics, 88, 70-89.

Davtyan, K. (2017). The distributive effect of monetary policy: The top one percent makes the difference. Economic Modelling, 65, 106-118.

Enders, W. (2015). Applied Econometric Time Series (4th Ed). United States: John Wiley \& Sons.

Furceri, D., Loungani, P., \& Zdzienicka, A. (2017). The effects of monetary policy shocks on inequality. Journal of International Money and Finance, 85(2017), 168-186.

Ghossoub, E. A., \& Reed, R. R. (2017). Financial development, income inequality, and the redistributive effects of monetary policy. Journal of Development Economics, 126, 167-189.
Guerello, C. (2018). Conventional and unconventional monetary policy vs. households income distribution: An empirical analysis for the Euro Area. Journal of International Money and Finance, 85, 187-214.

Gujarati, D. N., \& Porter, D.C. (2008). Basic Econometrics (5th Ed). New York: The McGraw-Hill Companies.

Kang, S. J., Chung, Y. W., \& Sohn, S. H. (2013). The effects of monetary policy on individual welfares. Korea and the World Economy, 14(1), 1-29.

Koedijk, K. G., Loungani, P., \& Monnin, P. (2018). Monetary policy, macroprudential regulation and inequality: An introduction to the special section. Journal of International Money and Finance, 85, 163-167.

Lütkepohl, H., \& Kratzig, M. (2004). Applied Time Series Econometrics (Themes in Modern Econometrics). Cambridge University Press.

Mishkin, F. S. (2016). The Economics of Money, Banking, and Financial Markets (11th Ed). United States of America: Pearson Education Inc.

Mumtaz, H., \& Theophilopoulou, A. (2017). The impact of monetary policy on inequality in the UK. An empirical analysis. European Economic Review, 98, 410-423.

Nakajima, M. (2015). The Redistributive Consequences of Democratization, of Monetary Policy. Business Review., (Second Quarter), 9-16.

Romer, C. D., \& Romer, D. H. (1999). Monetary Policy and the Wellbeing of the Poor. Economic Review, Federal Reserve Bank of Kansas City, (Q1), 21-49.

Saiki, A., \& Frost, J. (2014). Does Unconventional Monetary Policy Affect Inequality? Evidence from Japan. Applied Economics, 46(36), 4445-4454. 
United Nations Development Programme. (2013). Humanity Divided:Confronting Inequality in Developing Countries.

Villareal, F. G. (2014). Monetary Policy and Inequality in Mexico. MPRA Paper 57074.

Warjiyo, P., \& Juhro, S. M. (2016). Kebijakan Bank Sentral: Teori dan Praktik. PT Raja Grafindo Persada.

World Bank. (2016). Ketimpangan Yang Semakin Lebar http://pubdocs. worldbank.org/en/986461460705 141518/Indonesias-Rising-DivideBahasa-Indonesia.pdf. tanggal 15 Februari 2018 